(3) Fe-Mn-V, Fe-Mn-Mo ならびに Fe-Mn-Si 系の $\alpha / \gamma$ 平衡組成をX線マイクロアナライザーによって決定し， $x_{\mathrm{Mn}} / x_{\mathrm{X}}=1$ の切断状態図を作成した。これらの系のてル一 プは理論的に尒想された状態图と全く一致することがわ かった。
終りにマイクロアナライザーの使用について抴話にな った東北大学工学部, 渡迢 融博士, 須田恭三氏,ならびに 有益な即言を戴いた同大学院，長谷部光弘氏に愿く感謝致 しま寸。亦た試料の分析に御援助いただいた同金属材料研 究所, 増本 健教授, 坂本政祀博士に当謝意を表し 主。

\title{
$18 \mathrm{Cr}$ 鋼の高温酸化被膜構造におよぼす 結晶粒度および粒成長の影響
}

\section{中 山忠 行 $^{*}$ 堀 部進**}

Tadayuki Nakayama and Susumu Horibe : Effects of Grain Size and Grain Growth on the Structures of Oxide Films Formed on $18 \mathrm{Cr}$ Steel. The effects of grain size and grain growth on the structures and compositions of oxide films produced on the surfaces of $18 \mathrm{Cr}$ steel heated in air at $600 \sim 1100^{\circ} \mathrm{C}$ for $5 \mathrm{hr}$ or $10 \mathrm{hr}$ were investigated through transmission electron diffraction, X-ray diffraction and X-ray microanalysis methods.

The main results obtained are as follows :

(1) The oxide films formed on large grain specimens (grain size; ca. $1600 \mu$ ) heated at $600 \sim 800^{\circ} \mathrm{C}$ for $5 \mathrm{hr}$ were composed of a corundun-type oxide containing $\mathrm{Fe}$ and $\mathrm{Cr}$, was on fine grain specimens (grain size; ca.10 $\mu$ ) spinel type oxide consisting mainly of $\mathrm{Cr}$ and $\mathrm{Mn}$ was formed besides the corundum type oxide. The spacings obtained from the oxides produced on both specimens heated at $900^{\circ} \mathrm{C}$ for $10 \mathrm{hr}$ coincided with those of $\mathrm{Cr}_{2} \mathrm{O}_{3}$ and $\mathrm{MnCr}_{2} \mathrm{O}_{4}$ crystals. At these temperatures both specimens did not indicate the grain growth of ferrite matrices.

(2) A fine grain specimen was covered with thick oxide layers after heating at $1000^{\circ} \mathrm{C}$ for $5 \mathrm{hr}$ and at that temperature the grain growth was predominant. The outer layer consisted of $\alpha-\mathrm{Fe}_{2} \mathrm{O}_{3}$ and $\mathrm{Fe}_{3} \mathrm{O}_{4}$, and the imer layer was identified with $\mathrm{FeCr}_{2} \mathrm{O}_{4}$. On the other hand, at this temperature a large grain specimen was still covered with the same oxide as that formed at $900^{\circ} \mathrm{C}$.

It is reasonable to consider that this singular oxidation behaviour in the fine grain specimen is due to the occurrence of cracks in the oxide film by boundary migration in the matrix during oxidation.

(Received July 23, 1973)

\section{I. 緒言}

Fe-Cr 系あるいはFe-Ni-Cr 系ステンレス鋼の各種高温 環境下での腐食举動に関しては，工業的にも重要な問題で あるところからすでに多くの研究が行われ，またこれら合 金の高㬈水蒸気中に扣ける酎食性に拈上ぽす結晶粒度の影 響についても，すでていくつかの與味ある報告(1)〜(3)がな されている，しかしながら従来のステンレス鋼の高昷酸化 挙動こ関する研究は，その再結鼠あるいは粒成長鼬度以下゙ でのものが主体であり，それ以上の温度領域での酸化過程

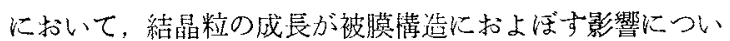
てはいまだ明確な知兒が得られていない，また一般に耐熱 金属忉料が高温酸化環賞下で使用に供される場合，材料が 加工による歪を受けているために酸化過程に粒成長が起こ

* 早稻田大学理工学部金属工学科(Department of Metallurgical Engineering, Faculty of Science and Engineering, Weseda University, Tokyo)

** 早稱田大学大学院 (Graduate School, Waseda University, Tokyo)
りこれが酸化挙動に影響をおよばすことが考えられる。 本研究においては比較的熱膨張が少なく，生成酸化被膜 が安定である $18 \mathrm{Cr}$ 鋼について大気中の酸化挙動，とくに 生成酸化被膫構造におよぼす結晶粒度ならびに酸化過程に 扣计る素地結晶粒成長の影響について構造化学的究明を試 みた。

\section{II．試料および実験方法}

本研究に用いた $18 \mathrm{Cr}$ 鋼はSUS 430 亿相当した組成の厚 さ $1 \mathrm{~mm}$ の压延材で，その化学組成を Table 1 に揭げた。

な招本鋼恃冷間圧延後約 $800^{\circ} \mathrm{C}$ で宽鈍されたもので， フェライト粒径の平均值は約 $10 \mu$ であった。ささらにこの 压延材を $1250^{\circ} \mathrm{C} て ゙ 5 \mathrm{hr}$ 真空暁鈍して，ストアードェネル ギーを添济完全に解放するとともに，フニライト粒が約

(1) M.Warzee,J.Hennaut, M.Maurice,C.Sonnen and J.Waty : J.Electrochem.Soc., $112(1965), 670$.

(2) W.E.Ruther, R.R.Schlueter, R.H.Lee and R.K. Hart: Corrosion, 22(1966), 147.

（3）小若正倫，永田三郎：金属学会誌，36(1972)，486. 
Table 1 Chemical composition of material (wt $\%$ )

\begin{tabular}{c|c|c|c|c|c}
\hline $\mathrm{C}$ & $\mathrm{Si}$ & $\mathrm{Mn}$ & $\mathrm{P}$ & $\mathrm{S}$ & $\mathrm{Cr}$ \\
\hline 0.06 & 0.71 & 0.71 & 0.032 & 0.005 & 17.11 \\
\hline
\end{tabular}

$1600 \mu$ に成長した試料を作製した。これら粒径の異なる両 試料からそれぞれ $15 \mathrm{~mm} \times 20 \mathrm{~mm}$ の試片を切り出し，真 空暁銛のさい生成した試料表面の $\mathrm{Cr}$ p $\mathrm{Mn}$ の欠之層を機 械研摩により完全汇除去し，さらにェメリ一紙０5 で研摩 仕上げ後，アセトンにて脱脂洗浄して酸化実駼に供した。

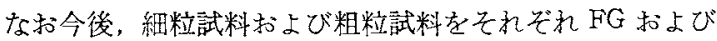
LG と名付计る.

これら両試料はいずれも所定の酸化温度 $\left(600 \sim 1100^{\circ} \mathrm{C}\right)$ まで $25^{\circ} \mathrm{C} / \mathrm{min}$ の昇温速度で加熱後, $5 \mathrm{hr}$ もしくは $10 \mathrm{hr}$ 大気中保持の酸化を行い，生成する酸化物の究明を試及 た。な打試料が所定の酸化温度に到達する間にも，試料表 面には酸化被膜の生成を見るが，ここで一定の昇温速度を 用いたのは，昇温速度が異なれぱこの間に生成する被膜の 構造あるいは厚さなども異なり，これらがその後の所定温 度での保持期間中に生成する酸化被膜構造に影響を和上涪 すことを考虑したためである。

$800^{\circ} \mathrm{C}$ まで温度領域に求いて生成した薄い酸化層につ いては, $\mathrm{Br}_{2}-\mathrm{CH}_{3} \mathrm{OH}$ (容積比 1:200) 常温溶液中に 約 $8 \mathrm{hr}$

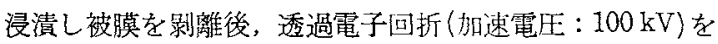
試みるとともに，同一視野からの特性X線分析(加速電生； $25 \mathrm{kV}$ ，ビーム径；約 $4 \mu$ )を行った。 また $900^{\circ} \mathrm{C}$ 以上の温 度領域において生成した厚化スケールの解析には，X楾回 折括よびX線マイクロアナライザーを用いた。ささらに酸化 後の各試料のフェライトマトリックス粒径の変化を測定 し，酸化物構造および組成との関連栍を検討した。

\section{ய、実験結果および考察}

\section{1. 粒成長が起こらない温度領域での酸化被膜構造}

大気中で $600^{\circ} \mathrm{C}, 5 \mathrm{hr}$ の酸化を行うことによって，LG 試料はもとより FG 試料においてもマトリックスの粒成長 は認められなかった。このさい表面に生成した酸化被膜の 透過電子回折像は，LG 試料上のものが コランダム型結晶 の夕の存在を示すの対し，FG 試料上のそれはコランダ ム型結晶以外に強度はきわめて弱いが若干のスピネル型結 晶の回折線を含んでいた(Photo.1(a)抢よび(b))。また LG 試料上の生成被膜の与える特性 X線スペクトルは，Fig.1 (a)に示すとおり $\mathrm{Fe}$ および $\mathrm{Cr}$ の存在を示すが，FG 試料 上のそれからはFig.1(b)《揭げたと和り $\mathrm{Fe}, \mathrm{Cr}$ 以外に明

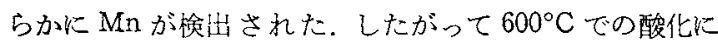
おいては粒界移動の影輹を考慮する必要はないが，粒度の 大小は $\mathrm{Mn}$ の拡散の促進に若干の影響をおよぼすことが明 らかとなった。しかもこの表面に拡散した $\mathrm{Mn} か ゙ ~ \mathrm{MnCr}_{2} \mathrm{O}_{4}$ あるいは $\mathrm{MnFe}_{2} \mathrm{O}_{4}$ などのスピネル型酸化物として生成し，
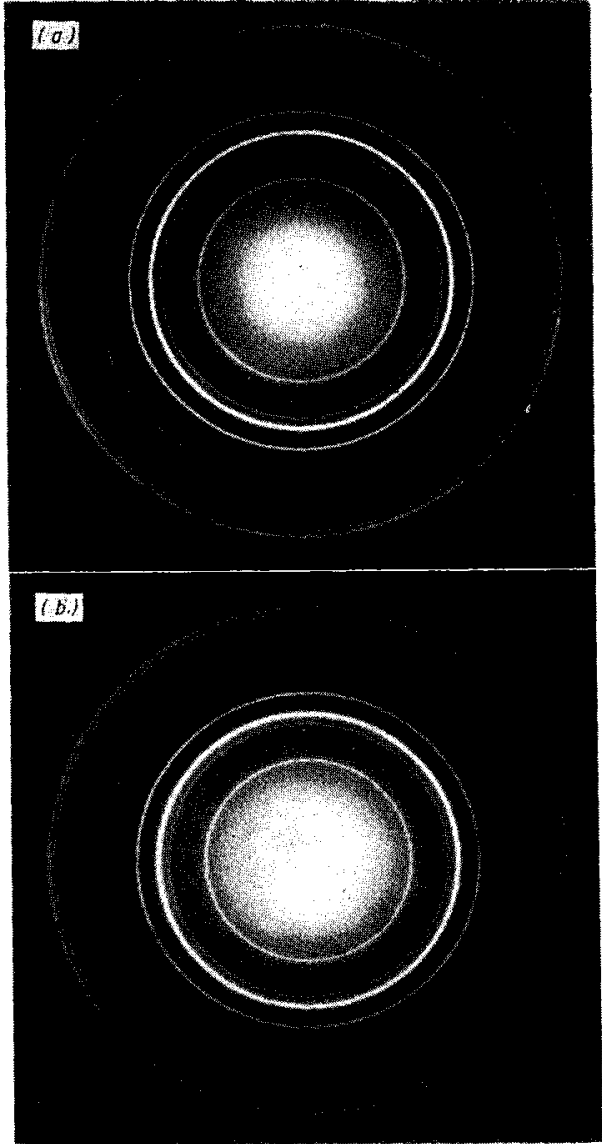

Photo.1 Electron diffractograms of a corundum type oxide formed on a large grain specimen (a) and mainly corundum type oxide produced on a fine grain specimen (b) in air at $600^{\circ} \mathrm{C}$ for $5 \mathrm{hr}$

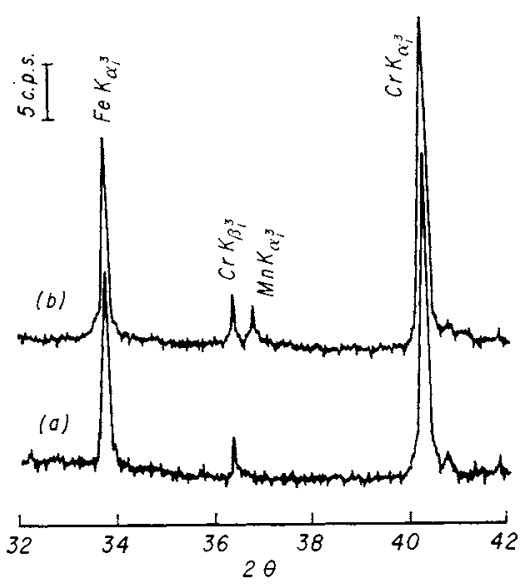

Fig. 1 Characteristic X-ray spectra obtained from the oxide films produced on a large grain specimen (a) and a fine grain specimen (b) in air at $600^{\circ} \mathrm{C}$ for $5 \mathrm{hr}$

これが FG 試料表面に生成した酸化被膜の与兄る回折線に ュランダム型結晶以外にスピネル型結晶からのるのを含ん だ原因と考えられる。 


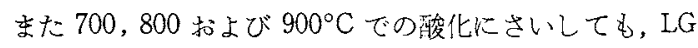
試料括いては粒成長が全く見られなかったが， $F G$ 試料 に执いても $700^{\circ} \mathrm{C}$ 拈よび $800^{\circ} \mathrm{C}$ では約 $10 \mu, 900^{\circ} \mathrm{C}$ では約

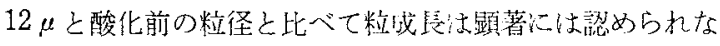
い. $700^{\circ} \mathrm{C}$ 㧍よび $800^{\circ} \mathrm{C}$ でLG試料敵面に生成した被膜

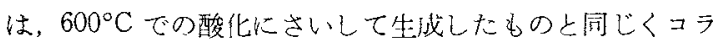

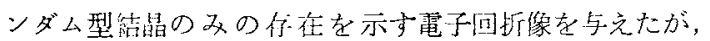
同温度領琙で FG 試料表面に生成した被膜は， $600^{\circ} \mathrm{C}$ の場

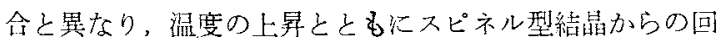
折線を顕著に字克た(Photo.2)。李たFig.2の特性X線ス ペクトルから明らかなよらに，加熱温度が高くなると両試 料とも生成酸化被膜中には Fe に比して $\mathrm{Cr}$ 召富化し，と りわ細粒の FG 試料炕いてはこの增え方が著しく，さ

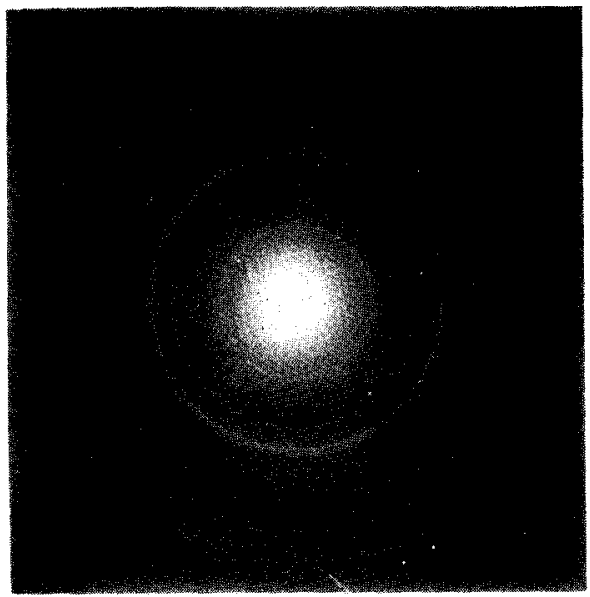

Photo.2 Electron diffractogram of corundum and spinel type oxides formed on a fine grain specimen in air at $800^{\circ} \mathrm{C}$ for $5 \mathrm{hr}$

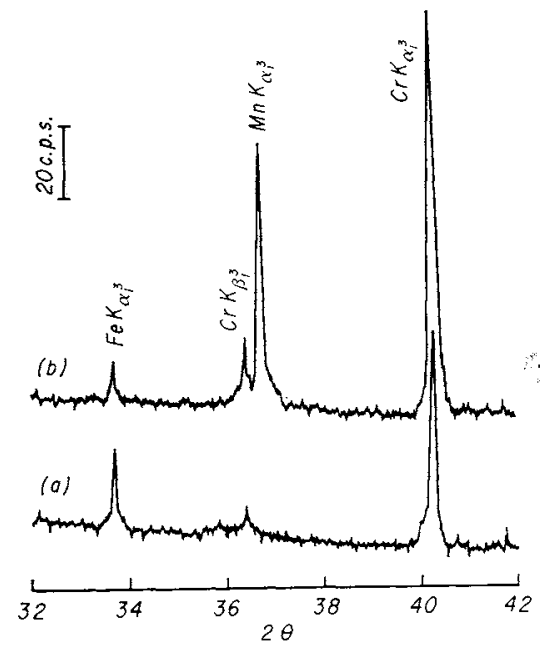

Fig.2 Characteristic X-ray spectra obtained from the oxide films produced on a large grain specimen (a) and a fine grain specimen (b) in air at $800^{\circ} \mathrm{C}$ for $5 \mathrm{hr}$

(4) A.S.T.M. X-ray powder data card, No.6-504. (5) A.S.T.M. X-ray powder data card, No.10-319.
らに FG 試料上の生成被腸中からは $600^{\circ} \mathrm{C} の$ 場合に比し てMnが多量に検计された。これは維㛙試料の晹合には 粗粒武料の場合江比し粒界拉散径路が多いために，かかる 酸化温度で京とくにCr户 Mnの化した酸化物の生成を 見たものと考えられる。したがって FG 試料の場合には，

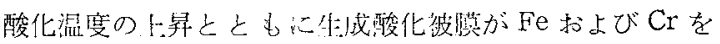
主体としたコランダム型骋化物から Cr 㘧よび Mn を主体 とした $\mathrm{MnCr}_{2} \mathrm{O}_{4}$ などのスピネル型酸化物へ変化したこと

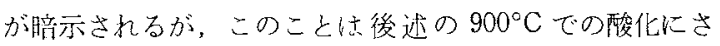
いしての生成被膜構造の解明によっても明らかなよらであ る，な和細粒試料表面上の主成酸化屬には粗粒試料表面上. のもの以比して Crが窑化する現象は，高淔水蒸気中にお けるステンレス鋼表面上の生成スケールKついて瑟めら れている(3).

つぎに $900^{\circ} \mathrm{C}$ の大気中で $5 \mathrm{hr}$ 酸化することによって生

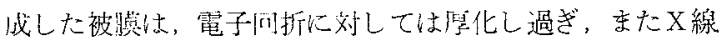
㛠折に坟しては簿すぎるため，10 hr の酸化を試みたとこ 万，X線!折結果はFig.3 に示すよ5に FGならびに LG

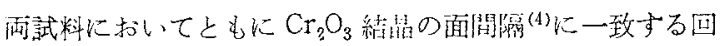

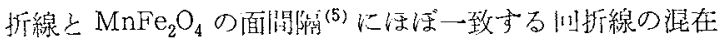
から成っていることが判明した。しかしながら $\mathrm{MnCr}_{2} \mathrm{O}_{4}$ の 格子定数 $(a=8.436 \AA)^{(6)}$ が $\mathrm{MnFe}_{2} \mathrm{O}_{4}$ の格子走数 $(a=8.499$ Å) ${ }^{(5)}$ と近く，またFig.4 江示した特性X總分析の結果， 被㯰中で Cr户 Mn 比してFeが極めて少ない事実を考 䍐すると，生成したスピネル型酸化物は主として $\mathrm{MnCr}_{2} \mathrm{O}_{4}$

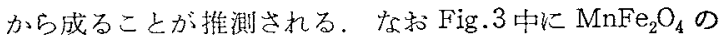
示与面間隔执よび回折強度を採用したのは，上述のように 格子定数が類似する $\mathrm{MnCr}_{2} \mathrm{O}_{4}$ に関してX線间折強度につ いての報告が得られていないためである。

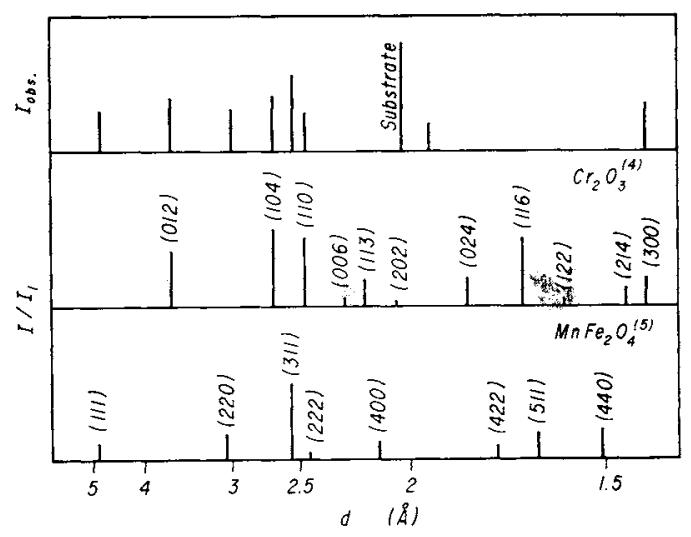

Fig.3 X-ray diffraction pattern of the oxide on a fine grain specimen heated in air at $900^{\circ} \mathrm{C}$ for $10 \mathrm{hr}$

\section{2. 粒成長が起こる温度領域での酸化被膜構造} $1000^{\circ} \mathrm{C}, 5 \mathrm{hr}$ の酸化にさいしては, FG 試料表面は $900^{\circ} \mathrm{C}$,

(6) O.Krause and W. Theil: On Ceramic Coloring Matters,Ber.d.Keram.Ges., 15(1934), 101. 


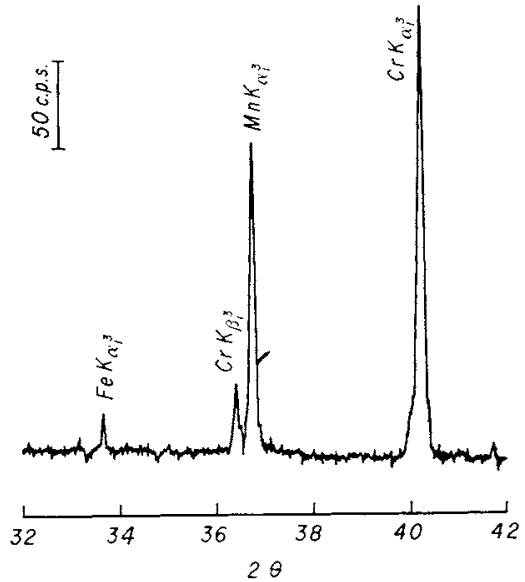

Fig.4 Characteristic X-ray spectrum obtained from the oxide film produced on a fine grain specimen in air at $900^{\circ} \mathrm{C}$ for $5 \mathrm{hr}$

$5 \mathrm{hr}$ あるいは $10 \mathrm{hr} の$ 酸化で生成したものと類似した漼 いスケールで被覆された部分以外は，約 $70 \mu$ に星化した スケールによって覆われた(Photo.3)。この愿化スケール 断面の特性X緗像(Photo.4)を調へたたころ，スケールは 層状構造を成し，外畨にはCr が存在せず，また内層にお

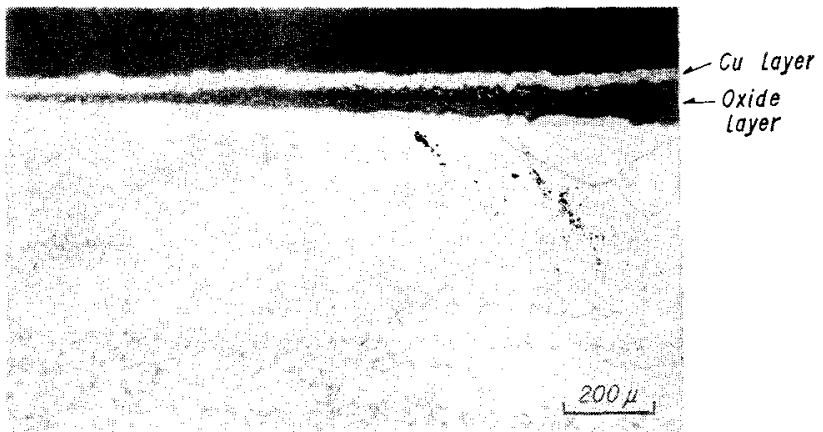

Photo.3 Microstructure of the cross section of a fine grain specimen heated in air at $1000^{\circ} \mathrm{C}$ for $5 \mathrm{hr}$

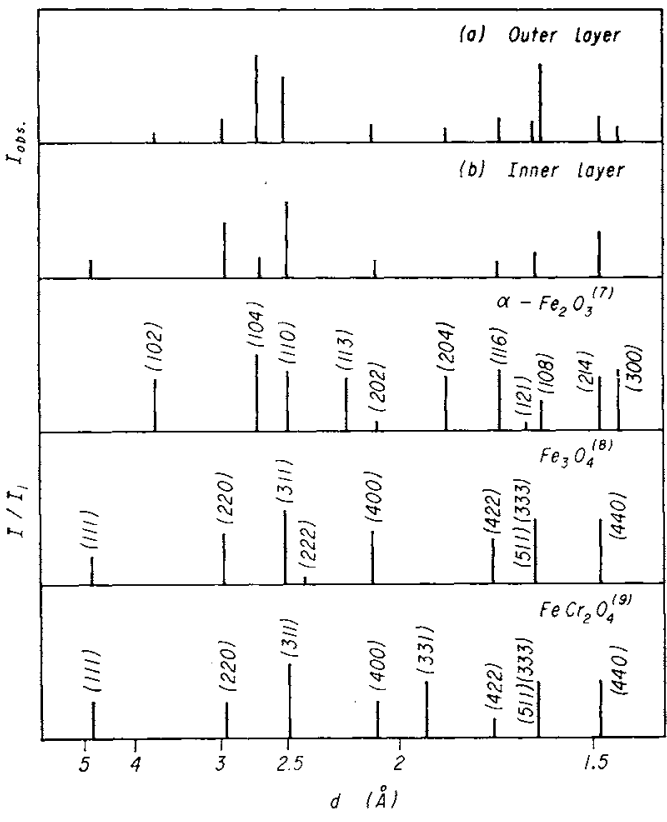

Fig.5 X-ray diffraction patterns of the outer layer (a) and the inner layer (b) of the oxide scales on a fine grain specimen heated in air at $1000^{\circ} \mathrm{C}$ for $5 \mathrm{hr}$

けるFeは外層およびマトりックス中における Fe よりる少ないことが判る。さらに Fig.5に示したこ の厚化スケールのX線回折結果によれば，外層は二 ランダム型酸化物括よびスピネル型酸化物からの回 折線を与えたのに対し，素地と接する内層は主と してスピネル梨酸化物から成ることが判明した。 これらX線回折結漹と特性X線像の結果とを考虑す ることにより，外層中に含本れるコランダム型酸化 物は $\alpha-\mathrm{Fe}_{2} \mathrm{O}_{3}$ ，スピネル型酸化物は $\mathrm{Fe}_{3} \mathrm{O}_{4}$ から成り， 内層のスピネル型酸化物は $\mathrm{FeCr}_{2} \mathrm{O}_{4}$ 主体とするこ とが明らかとなった。また厚さ約 $3 \mu$ の薄いスケー

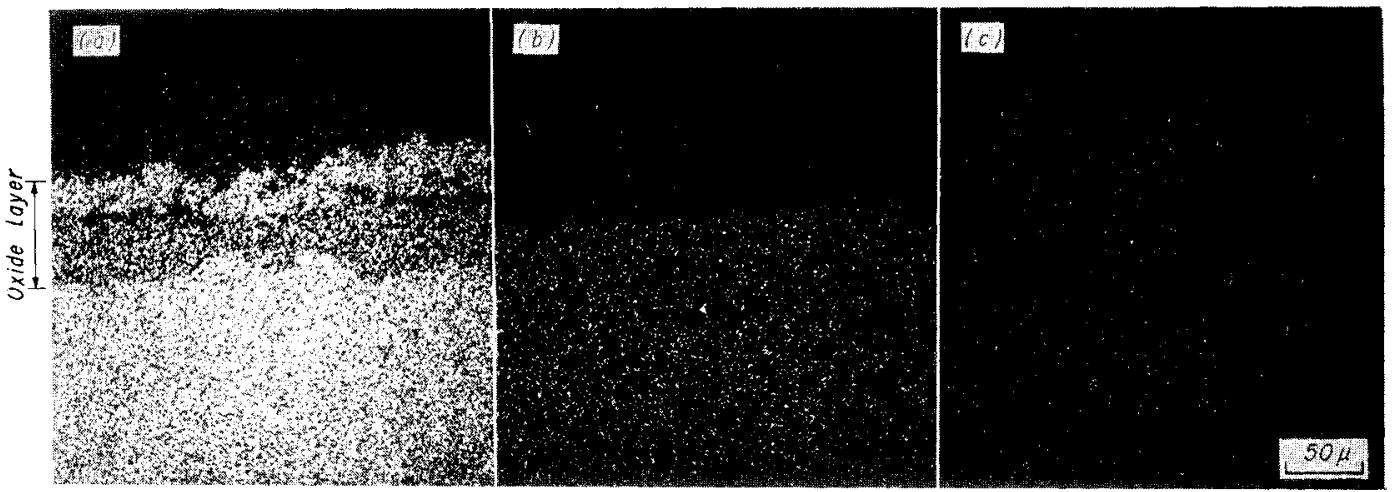

Photo.4 Characteristic X-ray images obtained from the cross section of a fine grain specimen heated in air at $1000^{\circ} \mathrm{C}$ for $5 \mathrm{hr}$. (a) $\mathrm{Fe} K_{\alpha}$ image, (b) $\mathrm{Cr} K_{\alpha}$ image, (c) $\mathrm{Mn} K_{\alpha}$ image

(7) A.S.T.M. X-ray powder data card, No.6-502.

(8) A.S.T.M. X-ray powder data card, No.11-614.
(9) A.S.T.M. X-ray powder data card, No.4-759. 
ルで被㠅された箇所のX線回折を行ったところ，900ㄷ゙ 生成したスケールと同一で，主として $\mathrm{Cr}_{2} \mathrm{O}_{3}$ から成るコラ ソダム型結晶と $\mathrm{MnCr}_{2} \mathrm{O}_{4}$ 主体のスピネル型結晶から成る 酸化物であった。

なお同試料の酸化後のフェライトマトリックスの平均粒 径はPhoto.3に見られるよ5に，厚化スケール生成直下で は粗大化して約 $150 \mu$ となり，薄いスケールで被㻼されて

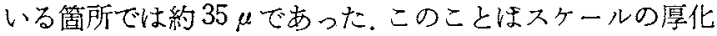
が酸化過程に括ける粒成長にともなら素地からの被膜の影 離もしく以被膜中に批るき裂発生に基づく break away によるものと考光られる，一方，粒成長の顕著でない部分 に対応した被膜が薄かったのは，被膜と素地との固着性の 失われていないことに基因するものと思われる。なおこの ように場所によって粒成長が異なった原因は試料内部のス トアードェネルギーの不均一性によるものであるう。

FG 試料の $1100^{\circ} \mathrm{C}, 5 \mathrm{hr}$ 酸化では, Photo.5に示すよう に試料表面は一面愿化スケールによって覆われたがここ の場合も層の厚さ愓所によってかなり不均一で，一部約 $180 \mu$ 亿達する厚化した部分を除いて全体的に $1000^{\circ} \mathrm{C} の$ 場合の厚化スケール層上り薄く，その平均厚さは $35 \mu$ であ った。 X線マイクロアナライザー钼察によれば，Photo.6 に揭げたよらにこのスケールは明らかに 2 層構造をなし， 外層は $\mathrm{Fe}$ から成り，内層灿 $\mathrm{Fe}$ および $\mathrm{Cr}$ から成る酸化物

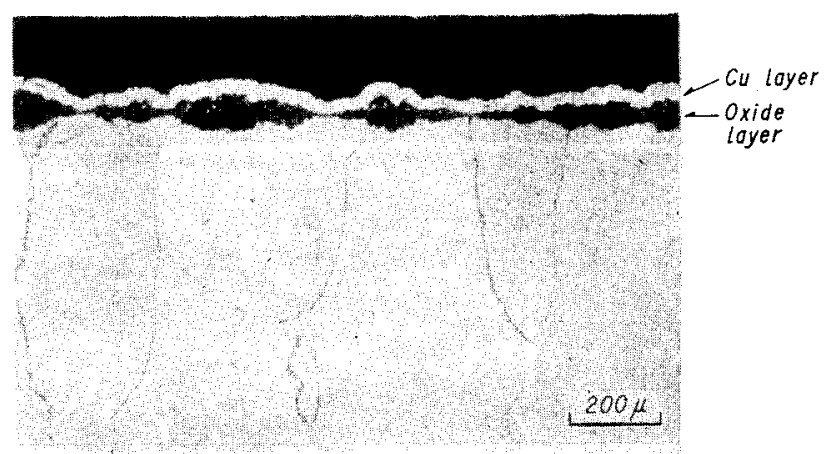

Photo.5 Microstructure of the cross section of a fine grain specimen heated in air at $1100^{\circ} \mathrm{C}$ for $5 \mathrm{hr}$

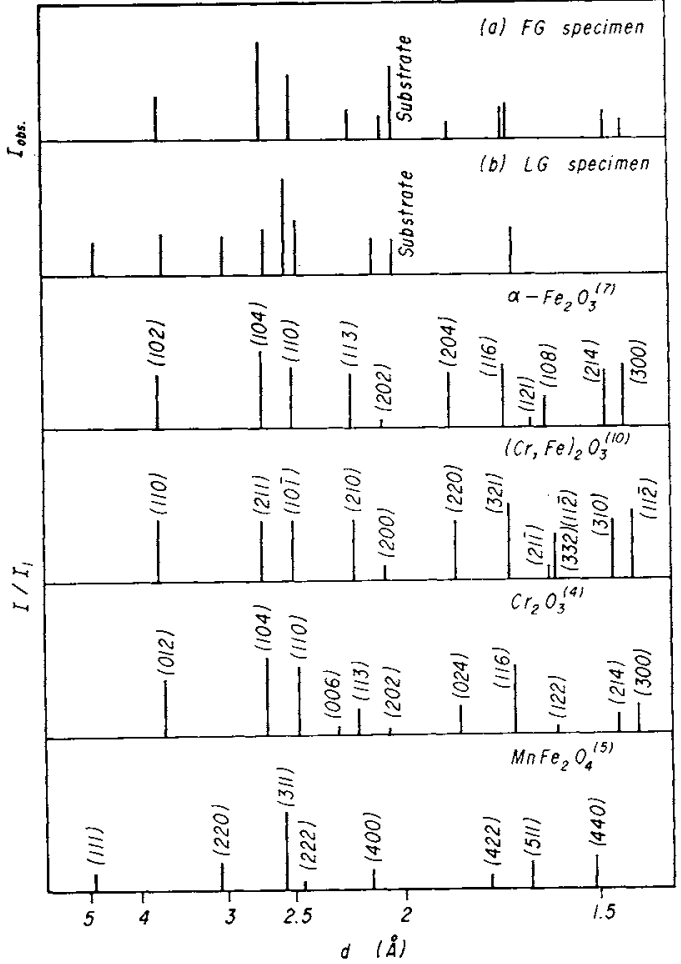

Fig.6 X-ray diffraction patterns of the oxides on a fine grain specimen (a) and a large grain specimen (b) heated in air at $1100^{\circ} \mathrm{C}$ for $5 \mathrm{hr}$

の标在を示した。しかも Fig.6(a)から明らかなよら に，このスケールの与光るX線回折線中にはスピネ ル型酸化物は济められず，コランダム型酸化物の回 折線のみを示した。これらの結果，FG 試料表面に $1100^{\circ} \mathrm{C}, 5 \mathrm{hr}$ の酸化で生成した 2 層構造スケールは 外層が $\alpha-\mathrm{Fe}_{2} \mathrm{O}_{3}$ から成り，内層が主として(Cr， Fe) ${ }_{2} \mathrm{O}_{3}$ から成ることが判明した。な叔この酸化後の フェライト粒は試料全域にわたってかなり成長して おり，その平均粒径は約 $240 \mu$ であったここよら に FG 試料では厚化スケール直下のマトリックス粒

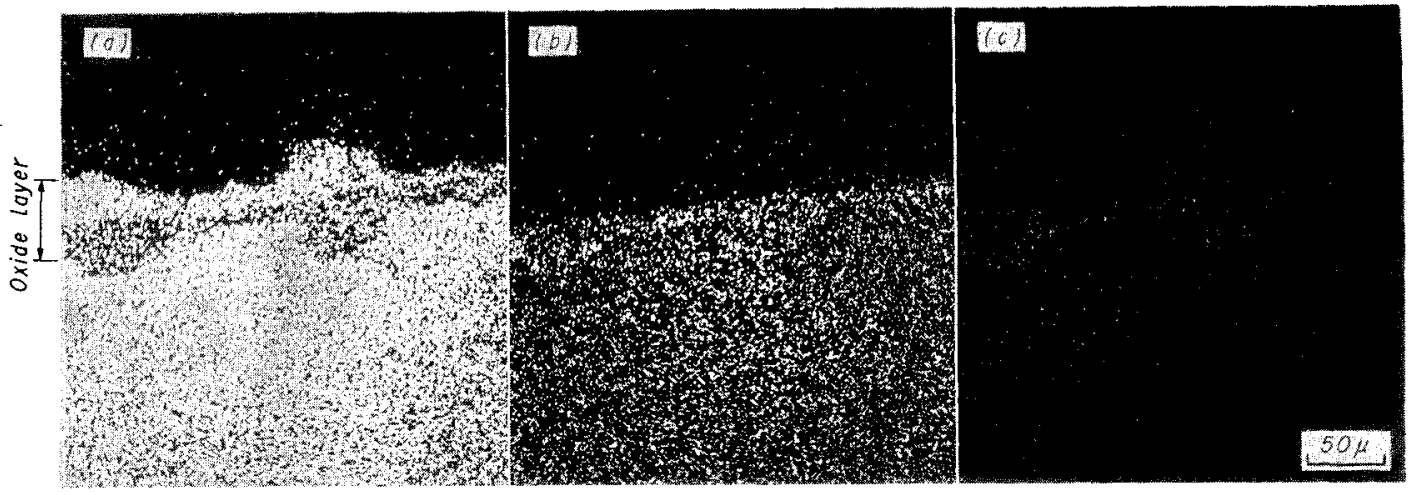

Photo.6 Characteristic X-ray images obtained from the cross section of a fine grain specimen heated in air at $1100^{\circ} \mathrm{C}$ for $5 \mathrm{hr}$. (a) $\mathrm{Fe} K_{\alpha}$ image, (b) $\mathrm{Cr} K_{\alpha}$ image, (c) $\mathrm{Mn} K_{\alpha}$ image

(10) A.S.T.M. X-ray powder data card, No.2-1357. 

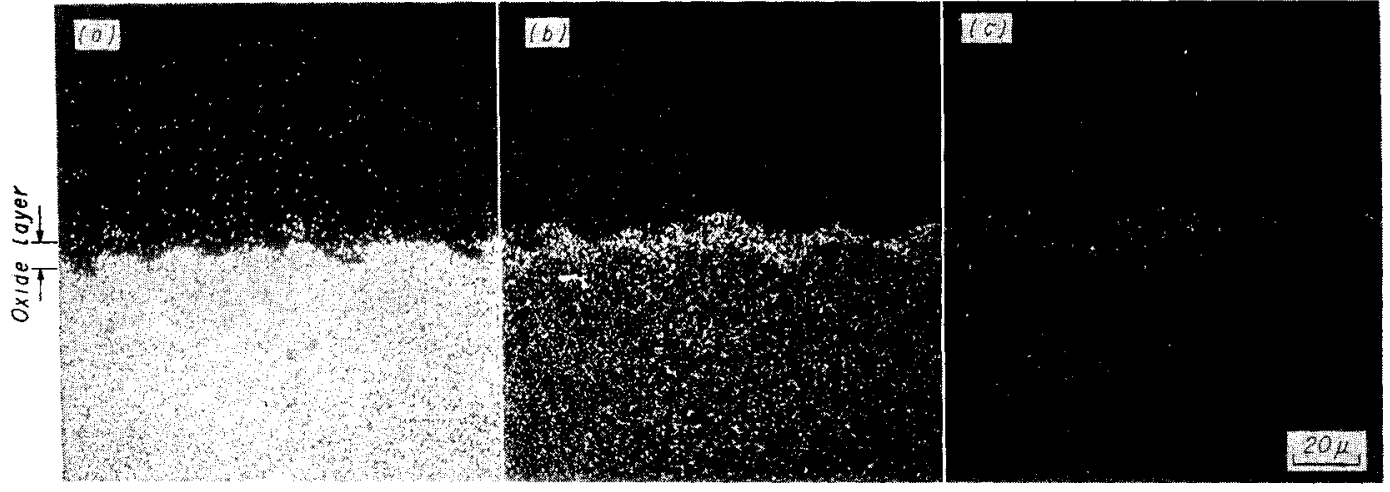

Photo.7 Characteristic X-ray images obtained from the cross section of a large grain specimen heated in air at $1000^{\circ} \mathrm{C}$ for $5 \mathrm{hr}$. (a) Fe $K_{\alpha}$ image, (b) $\mathrm{Cr} K_{\alpha}$ image, (c) $\mathrm{Mn} K_{\alpha}$ image

径が，酸化前のものに比して変しく成長しているのが特徽 的である。

一方 LG 試料上に $1000^{\circ} \mathrm{C}$ 和よび $1100^{\circ} \mathrm{C}, 5 \mathrm{hr}$ の酸化で生 成した被膜は，一例として示したPhoto.7の特性X線像あ るいはFig.6(b)のX線国折結果によれば，とるに $900^{\circ} \mathrm{C}$, $10 \mathrm{hr}$ の酸化の昜合と類似し, 主とし $\mathrm{C} \mathrm{Cr}_{2} \mathrm{O}_{3}<\mathrm{MnCr}_{2} \mathrm{O}_{4}$

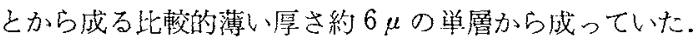
李た同試料では $1000^{\circ} \mathrm{C}$ るいは $1100^{\circ} \mathrm{C}$ での酸化前後で ともに粒径に全く変化が异られなかった。

これらの実験事実から，かかる温度領域での酸化にさい して,FG 試料が $900^{\circ} \mathrm{C}$ 以下での温度領域での酸化とも， また LG 試料とも異なった構造と組咸をもつ酸化物によっ て被覆された原因は，酸化過程に批けるマトリックスの粒 界移動によることが撨論される。この粒界移動に起因する 特異な酸化現象は，つぎのメカニズムを考えることによっ て説明でさるよらに思われる。すなわら FG 試料表面は昇 温過程の $900^{\circ} \mathrm{C}$ までの温度領域に执いては1。で述べたよ 5 な比较的緻密な $\mathrm{Cr}_{2} \mathrm{O}_{3}$ と $\mathrm{MnCr}_{2} \mathrm{O}_{4}$ 子から成る被膜によ って被覆され， $1000^{\circ} \mathrm{C}$ 以上の酸化過程でもマトリックス の粒成長が顕著には起こらない部分では，支の後の生成酸 化被獏に変化は生じないが，粒成長が著しく起こる部分で は，それまでに表面を被覆したこれら酸化物から成る被膜 あるいはそれとマトリックスの界面にき裂が生ずる。その さい酸化被膜層に接した Cr の不足した合金表面層が淔接 酸化雲围気と接し， $\mathrm{Cr}_{2} \mathrm{O}_{3} に よ る$ healing 層が生成され難 く，(Cr，Fe ${ }_{2} \mathrm{O}_{3}$ あるいは $\mathrm{FeCr}_{2} \mathrm{O}_{4}$ など Feを金む酸化物が 内嘪に生成されたものと考えられる。すなるら高温での酸 化過程でいわゆる break away 現象が現われたことが容易

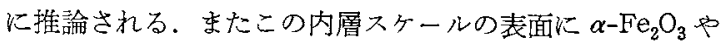
$\mathrm{Fe}_{3} \mathrm{O}_{4}$ がかなり厚く生成した原因は $\mathrm{Cr}_{2} \mathrm{O}_{3}$ 中に叔けるより 当 $(\mathrm{Cr}, \mathrm{Fe})_{2} \mathrm{O}_{3}$ あるいは $\mathrm{FeCr}_{2} \mathrm{O}_{4}$ 中での $\mathrm{Fe}$ の抾散が容易で あることによるものと考えられる。 とくに $1000^{\circ} \mathrm{C} て ゙$ 酸化

(11) D.Caplan and M.Cohen : J.Electrochem.Soc., 108 (1961), 438.

(12) C.S.Tedmon, Ir . : J.Electrochem. Soc., $113(1966)$, 766 .
した場合のようにフェライト粒成長が酸化過程で徐々に起 こる場合は，これらき裂発生と酸化進行のくり返しによっ てスケールが異常に成辰する。とこが同試料杂 $1100^{\circ} \mathrm{C} て ゙$ 酸化した場合は，より速やかにフェライト粒径が約 $220 \mu$ にまで成長し，粒成長が酸化の比較的初期段階に急激に起 こることが観察された。したがって被膜中あるいは被膜と 素地との界面に和けるき裂の発生も酸化初期に限られるこ

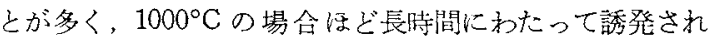
ないため，酸化雲国気との接触が少なくなり，酸化が抑制 されて $1000^{\circ} \mathrm{C}$ の場合よりも薄いスケールによって覆われ たものと推察される。

この他に $\mathrm{Cr}$ の酸化物が $\mathrm{CrO}_{3}$ となって揮発するため $1100^{\circ} \mathrm{C}$ で生成したスケールが薄くなることも考えられ る(11)(12)が， Feを主体とする外層スケールも内層同様に薄 く，粗粒試料では $1000^{\circ} \mathrm{C}$ 打よび $1100^{\circ} \mathrm{C}$ で生成したスケ ールに厚さの差がはとんど認められない事実から，揮発現 象がスケールの厚さに影響を秥よぼしているとは考学難 W.

一方かかる粒成長が起こる $1000^{\circ} \mathrm{C}$ 以上の高温領域では 粒内拡散が非常に活発となり，生成酸化物の構造組成にお よぽす粒界拡散の占める役割りはかなり少なくなると思わ れる、しかしながら合金内部で急速に移動している粒界を 径路とする成分元素の应散についても一応考虑しておくこ とが必要であるう，粒界移動が起こる高温領域では，粒界 に和ける元素の搪散が同じ状態で起こることはあり得な い、粒界移動の活性化エネルギーは成分元素の粶界払散の 活性化エネルギーに应隹等しいと言われている(13)〜(15) た め，粒界に存在するかもしく位粒界に拡散してきた原子 (ここでは主として Crおよび $\mathrm{Mn}$ )は粒界移動によって高 々数原子距離だけ動かされるにすぎないと考えるのが变当 である、つまり事実上，粒界移動が起こることによって粒

(13) P.A.Beck,P.R.Sperry and H.Hu : J.Appl.Phys., $21(1950), 420$

(14) D. Turnbull : Trans. AIME, 191 (1951), 661.

(15) E. L. Holmes and W.G. Winegard : Acta Met., 7 (1959), 411. 
界拆散は阻止されるであるう。したがって粒成長が起こら ない温度領域では粒度の差が成分元素の拡散に，しいては 酸化物組成に明らが影響をおよぼしたが，粒成長が起こ っている状態での細粒試料 $(F G)$ における粒界昖散の寄与 は，粒成長が完了している粗粒試料(LG) に括訬るとれよ りもさらに少ないであろらことが推測される。しかしなが ら前述したようにこの温度領域では粒界拡散自体の占める 割合が少ないのであるから，この寄与の大小が両試料の被 膜楧造炕差を生じせしめた主たる原因であるとは考元難 W.

すなわち粒成長にともなら表面生成酸化被膜のき裂抢よ び酸化被膜と素地界面のき裂発生による break away 現象 が，粒度の異なる両試料表面の高温酸化被膜構造に差を与 えた主原因と考觉るのが合理的のようである。

また粒界移動の起こらない $L G$ 試料では， $1000^{\circ} \mathrm{C}$ 以上 の高温でも酸化スケール層やあるいはこれと合金層との界 面にき裂を発生することなく，FG 試料に比してはるかに 薄い主として $\mathrm{Cr}_{2} \mathrm{O}_{3}$ と $\mathrm{MnCr}_{2} \mathrm{O}_{4}$ から成る酸化物が生成さ れたものと考克られる。

\section{V. 結蓉}

$18 \mathrm{Cr}$ 鋼について, 平均粒径約 $10 \mu$ の細粒試料とそのス トアードェネルギーを解放した平均粒径約 $1600 \mu$ の粗粒 試料を $600 \sim 1100^{\circ} \mathrm{C}$ の温度領域で $5 \mathrm{hr}$ あるいは $10 \mathrm{hr}$ 大 気酸化させ，そのさい生成される酸化物の構造と組成に拉 よぽす結晶粘度および酸化過程に和ける粒成長の影響につ いて調べた結果，主としてつぎの二つの事塞が認められ た.

(1) 粘成長が汪とんど起こらない温度領域 $\left(600 \sim 800^{\circ} \mathrm{C}\right)$ での酸化では，粗粒試料上に生成した被膜がコランダム型 酸化物のみから成っていたのに対して，組粒試料上に生成 した被膜にはこの他にスピネル型酸化物が含まれており，
酸化湍度の上昇とともに酸化被膜中にこのスピネル型酸化 物の占める割合は增加し，また $\mathrm{Cr}$ 拉よび $\mathrm{Mn}$ 量の増加る 顕著に垫めら机た。こ札は酸化物生成のために表面に拡散 する元素のらち，Cr括ょび Mn に関しては粒界拡散が大 きな比重を占めていることを暗示している．宝たこの表面 に拡散した Mnが細粒試料においてコランダム型酸化物 以外にスピネル型酸化物を生成した原因と考えられる。さ らに酸化温度が $900^{\circ} \mathrm{C}$ に達すると，粒度の差に関係なく主 として $\mathrm{Cr}_{2} \mathrm{O}_{3}$ から成るコランダム型酸伦物と $\mathrm{MnCr}_{2} \mathrm{O}_{4}$ を 主体とするスピネル型酸化物の生成が羿められた。

(2) 粒成長が䡩著に認められる温度領域 $\left(1000 \sim 1100^{\circ} \mathrm{C}\right.$ ) での酸化挙動は前述の場合と大きく異なった。すなるち， 粗粒試料では粒成長が起こらないため, 組成的にる構造的 にも $900^{\circ} \mathrm{C}$ の場合之同し酸化物を生成したのに対して，粒 成長が進行する細粒試料上には層状構造をなす異常に厚化 したスケールが生成し，とくに外層は Fe の酸化物から成 っていた. $1000^{\circ} \mathrm{C} て ゙$ 生咸した酸化物は外層では $\alpha-\mathrm{Fe}_{2} \mathrm{O}_{3}$ お 上び $\mathrm{Fe}_{3} \mathrm{O}_{4}$ ，内層では $\mathrm{FeCr}_{2} \mathrm{O}_{4}$ であっだ。しかしながら

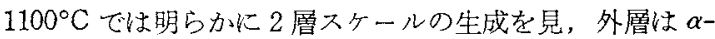
$\mathrm{Fe}_{2} \mathrm{O}_{3}$ ，内層は主として $(\mathrm{Cr}, \mathrm{Fe})_{2} \mathrm{O}_{3}$ から成っており，一部 異常に厚化した简所を除いて全体的に $1000^{\circ} \mathrm{C}$ で生成され たスケールよりも薄かった。

な招組粒試料江括汸粒成長後の生成酸化物の構造 之組成が粒成長前と異なった原因については，つぎのメカ ニズムが考えられる， $1000^{\circ} \mathrm{C}$ 越克る温度での酸化にさ いしては，昇温過程に表面被覆した主として $\mathrm{Cr}_{2} \mathrm{O}_{3}$ 々 $\mathrm{MnCr}_{2} \mathrm{O}_{4}$ から成る薄い被膜あるいはとれと素地との界面 に粒界移動によってき裂が生じ，いわゆる break away 現

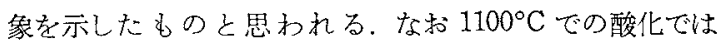
$1000^{\circ} \mathrm{C}$ の場合に比してより速やが粒成長が終了してし まう結果，被嚾のき裂発生に基すく大ケール成長は比較的 早く停止し， $1000^{\circ} \mathrm{C}$ の場合上りも屯し万薄いスケールに よって試料表面が被覆されたもの之考完られる。 